\title{
Fruit, Set of 'Success' Pecans Unaffected by Triphenyltin Hydroxide Fungicide Sprays during Pollination
}

\author{
William D. Goff ${ }^{1}$ \\ Department of Horticulture and Alabama Agricultural Experiment \\ Station, Auburn University, Auburn, AL 36849
}

Additional index words. Carya illinoensis, fentin hydroxide, fungicide, nut crops, alternate bearing, thinning

\begin{abstract}
Triphenyltin hydroxide fungicide sprays were applied at 114, 455, or 910 $\mathrm{g} \cdot \mathrm{ha}^{-1}$ either $\mathbf{0}, \mathbf{1}, \mathbf{3}, \mathbf{5}$, or 10 times during pollination of 'Success' pecans [Carya illinoensis (Wangenh.) K. Koch]. Pretreatment flower counts were compared to posttreatment fruit counts 7 and 9 weeks after pollination to determine if chemical rate or application frequency affected fruit set. There were no significant differences among rates, application frequency, or combinations in fruit drop ( $P>0.35$ in all cases). indicating that spraying this chemical did not affect fruit set. Chemical name used: triphenyltin hydroxide (fentin hydroxide).
\end{abstract}

Some pesticides used on pecans,. including triphenyltin hydroxide, reduce germination of pecan pollen and injure stigmatic surface cells (Wetzstein, 1989) and therefore potentially could reduce fertilization and fruit set if applied during or near pollination. Certain pesticides have been documented as having fruit-thinning effects (Williams and Edgerton, 1981). Commercial pecan growers commonly apply the fungicide triphenyltin hydroxide at 14-day intervals in early spring (Gazaway et al., 1989), likely during stigma receptivity or just before and after stigma receptivity.

Fruit thinning in pecans can improve nut

Received for publication 12 Oct. 1989. AAES Journal Series no. 11-892298P. Appreciation is expressed to Rhett Johnson, Dale Pancake, S.J. Parker, and Dara Kloss. The cost of publishing this paper was defrayed in part by the payment of page charges. Under postal regulations, this paper therefore must be hereby marked advertisement solely to indicate this fact.

'Associate Professor. quality and reduce alternate bearing (Sparks, 1975). 'Success' pecan is a severe alternate bearer, frequently producing large crops of low quality nuts in the "on" year, and small crops of higher quality during the "off' year. Chemical fruit thinning of pecan has met with limited success (Amling and Dozier, 1965; Dodge, 1944; Hinrichs et al., 1971; Sharpe, 1955; Smith and Harris, 1957; Wood, 1983), and has not been adopted commercially. It would be desirable if triphenyltin hydroxide, which is labeled for pecans and controls some diseases, could be used for fruit thinning. I therefore determined the effect of triphenyltin hydroxide applications during pollination on fruit set of 'Success' pecans during one season.

Sixty 'Success' pecan trees, 160 years old, in an experimental orchard near Andalusia in south central Alabama were selected. The trees were not irrigated but otherwise were maintained according to Alabama Cooperative Extension Service recommendations (Goff et al., 1989). The trees were in an alternate- bearing pattern and 1989, the year the sprays were applied, was anticipated to be a heavy crop year, following a light 1988 crop.

The design was a randomized complete block, with treatment combinations in a factorial arrangement for concentration of triphenyltin hydroxide, and frequency and time of application. Concentrations were 114,455 , and $910 \mathrm{~g} \cdot \mathrm{ha}^{-1}$ triphenyltin hydroxide, $1 / 4 \times$, $1 \times$, and $2 \times$ times, respectively, the rates recommended in Alabama (Gazaway et al. 1989). The formulation used was Super Tin 4L (Griffin Corp., Valdosta, Ga). The five frequency-timing of treatments were designated as 0 (no sprays during stigma receptivity), 1 (one spray only in middle of stigma receptivity), 3 (spraying every 4 days, three sprays total), 5 (spraying every 2 days, five sprays total), and 10 (spraying daily beginning at first day of stigma receptivity, 10 sprays total). There were four single-tree replications per treatment combination. At least one untreated buffer tree was maintained in every direction to minimize spray drift. Equipment breakdown prevented application of the last of the 10 sprays of 910 $\mathrm{g} \cdot \mathrm{ha}^{-1}$ in the daily schedule. Sprays were applied in 1122 liter of water per hectare, using an FMC air-blast sprayer, an application method and amount of water commonly used by commercial pecan growers (Gazaway et al., 1989)

Beginning of stigma receptivity was estimated (Smith and Romberg, 1941) to be the time when pollen would readily adhere to the stigmatic surface, in this case 28 Apr. 1989, the first day sprays were applied. Maximum receptivity was estimated to be 2 May. End of receptivity was estimated as the day when most stigmas had turned brown and dry, 7 May. Fifteen flower clusters per tree were selected and tagged. A pretreatment count of flowers in each tagged cluster was made on 4 and 5 May, i.e., after spraying began but presumably before fruit drop would have occurred because of insufficient pollination. Because flowers that are not fertilized drop within 6 weeks of pollination (Sparks and Madden, 1985), they again were counted on 
: Table 1. Fruit per cluster on pecan trees following sprays with triphenyltin hydroxide during the pollination period.

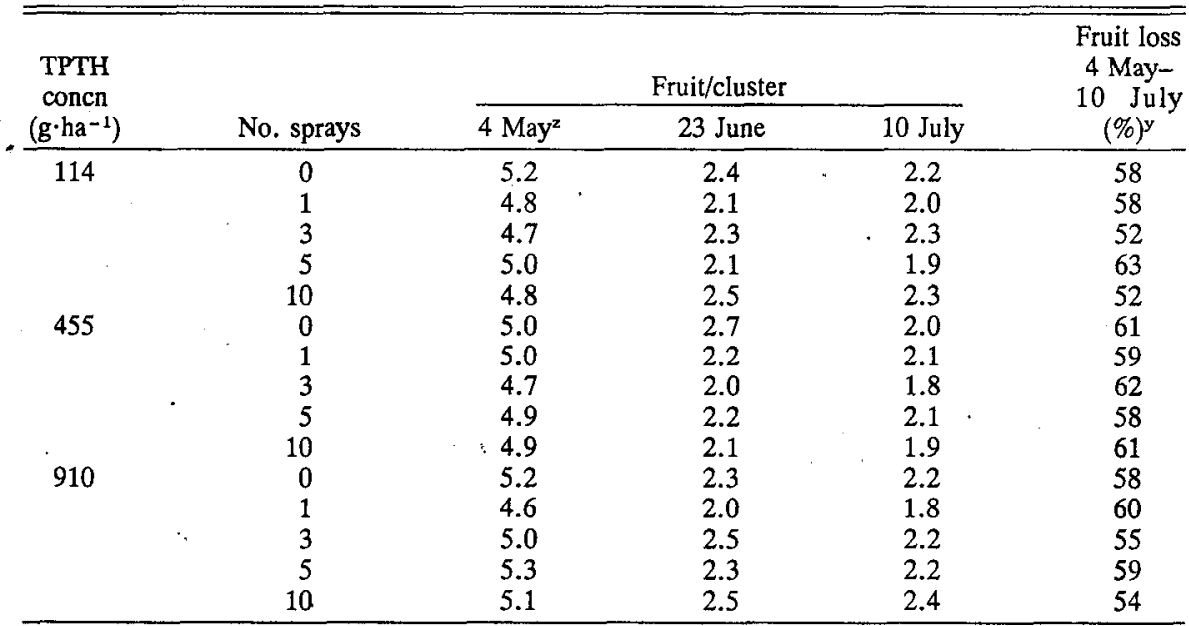

24 May was during the stigma receptivity period, 23 June and to July were $\approx 7$ and 9 weeks after pollination, respectively.

YThere are no significant differences in percent loss nor in fruit/cluster on any date due to rate, number of sprays, or combinations $(P>0.35$ in all cases).

23 June and 10 July, 7 and 9 weeks after pollination, respectively.

None of the variables, concentration of chemical, frequency of application, or ratefrequency combinations, affected fruit drop either 7 or 9 weeks after pollination ( $P>$ 0.35 in all cases) (Table 1).

Normal fruit drop (Sparks and Madden, 198.5) accounted for the loss of fruit observed in this experiment. The lack of differences in fruit drop among unsprayed trees and trees sprayed heavily during pollination suggests that rates and frequencies of application of triphenyltin hydroxide normally used during pollination by commercial pecan growers likely will not reduce pollination or fruit set of 'Success' pecans.

\section{Literature Cited}

Amling, H.J. and W.A. Dozier, Jr. 1965. Chem- Williams, M.W. and L.J. Edgerton. 1981. Fruit ical thinning of the Stuart pecan. Proc. Southeastern Pecan Growers Assn. 58:92.

Crane, H.L., M.B. Hardy, N.H. Loomis, and F.N. Dodge. 1934. Effect of nut thinning on size,

Sparks, D. and G.D. Madden. 1985. Pistillate flower and fruit abortion in pecan as a function of cultivar, time, and pollination. J. Amer. Soc. Hort. Sci. 110:219-223.

Wetzstein, H.Y. 1989. Inhibition of flower receptivity and pollination with fungicidal and insecticidal sprays. Proc. Southeastern Pecan Growers Awn. 82:49-53.

thinning of apples and pears with chemicals. U.S. Dept. Agr. Info. Bul. 289.

Wood, B.W. 1983. Fruit thinning of pecan with ethephon. HortScience 18:53-54 degree of filling, and annual yield of pecans. Proc. Amer. Soc. Hort. Sci. 32:29-32.

Dodge, F.N. 1944. Reducing the set of pecan nuts by spraying in flower with phytotoxicants. Proc. Amer. Soc. Hort. Sci. 45:59-62.

Gazaway, W., A. Latham, J. McVay, W. Goff, P. Estes, M. Patterson, and J. Everest. 1989. Commercial pecan disease, insect and weed control guide. Ala. Coop. Ext. Serv. Cir. ANR 27.

Goff, W.D., M.G. Patterson, and J.R. McVay. 1989. Pecan production. Ala. Coop. Ext. Serv. Cir. ANR-54.

Hinrichs, H.A., D. W. Ramming, and D.A. Hopper. 1971. Effects of ethephon on thinning nuts and loosening shucks of pecan. Annu. Rpt. Northern Nut Growers Assn. 62:105-108.

Sharpe, R.H. 1955. Tests on thinning of heavy pecan crops with growth regulators. Proc. Southeastern Pecan Growers Assn. 48:62-68.

Smith, C.L and O.W. Harris. 1957. Chemical thinning of pecan crops. Proc. Southeastern Pecan Growers Assn. 50:60-63.

Smith. C.L. and L.D. Rombere. 1941. Pollen adherence as a criterion of the beginning of stigma receptivity in the pecan. Proc. Texas Pecan Growers Assn. 21:38-45

Sparks, D. 1975. Alternate fruit bearing in pecans-a review. Pecan South 2(2):44-65. 